\title{
Development of a nucleic acid lateral flow immunoassay for simultaneous detection of Listeria spp. and Listeria monocytogenes in food
}

\author{
Martina Blažková · Marjo Koets · Pavel Rauch • \\ Aart van Amerongen
}

Received: 15 January 2009/Revised: 26 June 2009/ Accepted: 8 July 2009/Published online: 15 August 2009

(C) The Author(s) 2009. This article is published with open access at Springerlink.com

\begin{abstract}
We present a new nucleic acid lateral flow immunoassay (NALFIA) for the assessment of listeria contamination. The detection procedure starts with enrichment of sample in Half Fraser broth $(24 \mathrm{~h})$. Following isolation of DNA, a duplex PCR is performed with two labelled primer sets, one generic and directed to a specific sequence of the gene encoding 16S rRNA from Listeria spp. and the other specific and directed to a part of the $\operatorname{prf} A$ gene encoding the central virulence gene regulator from the food pathogen Listeria monocytogenes (3.5 h). The PCR solution is directly added to the one-step assay device and the appearance of a grey/black line is indicative of the presence of specific amplicons (max $15 \mathrm{~min}$ ). In all tests performed, the method correctly identified L. monocytogenes and strains of Listeria spp. PCR material of over 20 food samples was tested by NALFIA. The method proved to be useful for the detection of $L$. monocytogenes in different kinds of food samples.
\end{abstract}

Keywords Food-borne pathogen .

Immunochromatographic test - Nucleic acid lateral flow immunoassay (NALFIA) - Listeria monocytogenes .

Food $\cdot$ Nucleic acid testing $\cdot$ Nanoparticles

\footnotetext{
M. Blažková · P. Rauch

Department of Biochemistry and Microbiology, Institute of Chemical Technology Prague, Technicka 5, 16628 Prague 6, Czech Republic e-mail: martina.blazkova@vscht.cz

M. Koets · A. van Amerongen ( $\square)$

Biomolecular Sensing \& Diagnostics, Agrotechnology \& Food Sciences Group, Wageningen University and Research Centre, P.O. Box 17, 6700 AA Wageningen, The Netherlands e-mail: aart.vanamerongen@wur.nl
}

\section{Introduction}

Each year, millions of people become ill from food-borne diseases caused by Salmonella, Listeria, and Campylobacter [1]. For example, only in EU in 2005, it was reported in nearly 400,000 cases [2]. The effective control of food safety can be improved by the detection of pathogenic microorganisms with rapid methods. These should be simple, cost effective, easy to interpret, and with sufficient sensitivity and specificity.

The genus Listeria comprises six recognized species: $L$. monocytogenes, L. ivanovii ssp. ivanovii and londoniensis, L. innocua, L. welshimeri, L. seeligeri, and L. grayi. Listeria can survive and grow over a wide range of environmental conditions [3]. This allows the listeria to overcome food preservation and safety barriers [4]. Although occurrence of Listeria strains in food may indicate errors in good hygienic and manufacturing practice, only L. monocytogenes is a significant human and animal pathogen, which is responsible for severe invasive disease, listeriosis [5, 6].

Outbreaks caused by $L$. monocytogenes have been associated with ingestion of a variety of contaminated foods and were reported from many countries, including Australia, Switzerland, France, and the United States [7-10].

The minimum infective dose of $L$. monocytogenes has not been established. According to the Commission Regulation No 1444/2007, the food law of European Union insists on the absence of L. monocytogenes (not detectable in $25 \mathrm{~g}$ of food product) in ready-to-eat foods intended for infants and for special medical purposes. The ready-to-eat foods, other than those mentioned before, may contain $<100 \mathrm{cfu} / \mathrm{g}$ during their shelf life [11]. The standard isolation method for L. monocytogenes from food samples is described in ISO 11290-1 and 11290-2 [12]. Despite recent changes in ISO procedure, when application of modern 
chromogenic medium (Agar Listeria Ottavani \& Agosti) was included $[12,13]$, the total procedure takes 5-7 days, which is not optimal for testing foods with short shelf lives.

With the goal to overcome problems associated with traditional microbiological methods such as being time consuming and labour intensive many new modern techniques have been developed. They are based on either chromogenic media [14-16], antibodies [17-19], or nucleic acid-based techniques [20, 21]. Identification of Listeria spp. and L. monocytogenes using nucleic acid testing is becoming increasingly popular. The major advantage of these nucleic acid-based techniques is the fact that specificity is based on genomic sequences and does not rely on the expression of particular antigens or enzymes. In addition, nucleic acid-based methods can be extremely sensitive and specific. A number of test kits for Listeria are commercially available [22, 23].

The aim of this study was to develop a rapid and sensitive nucleic acid method for detection of L. monocytogenes in particular and the genus Listeria in general, with a substantially reduced pre-enrichment phase. For the detection of amplicons, we used a one-step nucleic acid lateral flow immunoassay (NALFIA) [24]. In this method, a small volume of the final PCR solution is directly added to the one-step assay device and the appearance of a grey/ black line is indicative of the presence of the specific amplicon. The visualization is mediated by using carbon nanoparticles. In the past years, nanoparticles were introduced as a detection tool in bioanalytics [25], which gives an alternative to conventional enzymatic or fluorescent labels, and enables easy and clear interpretation.

\section{Materials and methods}

\section{Cultures}

Strains of microorganisms used in the experiments are shown in Table 1. Cultures of Listeria and other bacteria were maintained on Petri plates of Oxford agar (Oxoid) or Brain Hearth Infusion Agar (Oxoid), respectively at $4{ }^{\circ} \mathrm{C}$. Prior to experiments, cultures were grown in $5 \mathrm{ml}$ Fraser Broth Base (Oxoid) at $37{ }^{\circ} \mathrm{C}$ for $18 \mathrm{~h}$.

Sample preparation

Model milk samples for verification of NALFIA were artificially contaminated with four different strains of $L$. monocytogenes (microbiological reference strain ALM 92 was tested in triplicate, $L$. monocytogenes NCTC 4886, $L$. monocytogenes NCTC 4885, and L. monocytogenes isolated from milk in the Institute of Food Research, Norwich, UK), two other Listeria subspecies (L. innocua, $L$. ivanovii), and Enterococcus faecalis. Decimal dilutions of overnight cultures of all tested bacterial strains were prepared. One $\mathrm{ml}$ aliquots of the cultures containing less than 10 cells were inoculated into flasks containing $25 \mathrm{ml}$ of sterilized milk. One non-contaminated milk sample was cultivated in the same way as a negative control.

The developed NALFIA was applied on real food samples which were prepared by the following procedure. Twelve food samples were collected from two supermarket chains, seven samples were obtained from one milk-producing biofarm in the Czech Republic, and five samples were part of internal lab trials.

All samples were cultivated according to the present standard isolation method for L. monocytogenes from food samples [12]. Flasks containing $225 \mathrm{ml}$ of Half Fraser broth (Oxoid) were mixed with $25 \mathrm{ml}$ or $25 \mathrm{~g}$ of food and incubated for $24 \mathrm{~h}$ at $37{ }^{\circ} \mathrm{C}$ whilst shaking. After this procedure, samples $(1 \mathrm{ml})$ were used for DNA isolation. The results were confirmed by the standard isolation microbiological method with confirmation on chromogenic agar ALOA (Agar Listeria according to Ottaviani and Agosti, Bio-rad). Total bacterial counts in solutions used in this study were determined by plating on BHI agar (Oxoid). The plates were incubated at $37^{\circ} \mathrm{C}$ for $48 \mathrm{~h}$.

\section{DNA extraction}

The DNA extractions from enriched samples were performed using a GenElute Bacterial Genomic DNA kit (Sigma), with the Gram-positive bacterial protocol.

Amplification of genetic material

A specific sequence $(1,003 \mathrm{bp})$ of the gene encoding $16 \mathrm{~S}$ rRNA from Listeria spp. was amplified by PCR using $5^{\prime}$ end labelled specific primers [26]. One was labelled with biotin (B, primer C: $5^{\prime}$-AGG TTG ACC CTA CCG ACT TC-3') and the other with fluorescein (FL, primer D: $5^{\prime}$ CAA GGA TAA GAG TAA CTG C- $3^{\prime}$ ). A set of primers [27] specific for L. monocytogenes was used to amplify a part ( $274 \mathrm{bp)}$ of the prfA gene encoding the central virulence gene regulator from this food pathogen. One of these primers was labelled with digoxigenin (DIG, primer LIP2: $5^{\prime}$-GTG TAA TCT TGA TGC CAT CAG G-3') and the other with biotin (primer LIP1: 5'-GAT ACA GAA ACA TCG GTT GGC-3'). The optimized composition of the reaction mixture was $2.5 \mu \mathrm{l}$ of FastStart Taq DNA Polymerase buffer $(500 \mathrm{mM}$ Tris $/ \mathrm{HCl}, 100 \mathrm{mM} \mathrm{KCl}, 50 \mathrm{mM}$ $\left.\left(\mathrm{NH}_{4}\right)_{2} \mathrm{SO}_{4}, \mathrm{pH} 8.3\right), 2.5 \mathrm{mM} \mathrm{MgCl} 2,0.15 \mathrm{mM}$ of dNTP, $2 \mathrm{U}$ of FastStart Taq DNA Polymerase (all from Roche), $0.1 \mu \mathrm{M}$ of primers LIP1 and LIP2, $0.2 \mu \mathrm{M}$ of primers C and $\mathrm{D}$, and $2 \mu \mathrm{l}$ of prepared template DNA. The final volume was adjusted to $25 \mu \mathrm{l}$ with distilled water. The 
Table 1 Strains of bacteria used in this study

\begin{tabular}{|c|c|c|c|}
\hline Species/strain (serotype) & Origin & Species/strain & Origin \\
\hline L. monocytogenes & Ref. material ALM 92, NCTC 13273 & Bacillus cereus & AFSG \\
\hline L. monocytogenes $(1 / 2 \mathrm{a})$ & NCTC 4886 & Enterobacter cloacae & Cabbage at STU \\
\hline L. monocytogenes (4b) & NCTC 4885 & Enterococcus faecalis & ССМ 2308 \\
\hline L. monocytogenes & Milk from IFR & Lactobacillus plantarum & CCM 7039 \\
\hline L. monocytogenes $(1 / 2 \mathrm{c})$ & NCTC 5348 & Enterobacter sakazakii & ATCC 29544 \\
\hline L. monocytogenes (4a) & NCTC 5214 & E. sakazakii & CCM 3460 \\
\hline L. monocytogenes (4b) & NCTC 10527 & Staphylococcus epidermidis & ATCC 12228 \\
\hline L. monocytogenes & NCTC 10888 & Staphylococcus aureus ssp. aureus & ATCC 25923 \\
\hline L. monocytogenes & Chicken from IFR & Proteus sp. & ССМ 1799 \\
\hline L. іппосиа & Salad from IFR & Escherichia coli & ATCC 8739 \\
\hline L. ivanovii & PHLS & Salmonella enterica ssp. enterica, enteritidis & ATCC 13076 \\
\hline L. seeligeri & ATCC 35967 & S. enterica ssp. enterica, typhimurium & ATCC 14028 \\
\hline L. grayi & ATCC 19120 & Serratia marcescens ssp. marcescens & ATCC 13880 \\
\hline L. welshimeri & NCTC 11857 & Pseudomonas aeruginosa & ATCC 27853 \\
\hline
\end{tabular}

NCTC UK National Collection of Type Cultures, ATCC American Type Culture Collection, PHLS UK Public Health Laboratory Service, IFR Institute of Food Research, Norwich, CCM Czech Collection of Microorganisms, AFSG Agrotechnology \& Food Sciences Group, The Netherlands, STU Slovak University of Technology, Slovak Republic

PCR was performed in the GeneAmp 9700 96-well thermal cycler (Applied Biosystems) with the following steps: an initial denaturation at $95{ }^{\circ} \mathrm{C}$ for 4 min, 25 cycles each having a denaturation at $94{ }^{\circ} \mathrm{C}$ for $30 \mathrm{~s}$, annealing at $55^{\circ} \mathrm{C}$ for $30 \mathrm{~s}$, and elongation at $74{ }^{\circ} \mathrm{C}$ for $1 \mathrm{~min}$ with a final extension at $74^{\circ} \mathrm{C}$ for $5 \mathrm{~min}$.

Following PCR, two types of double-labelled amplicons could be obtained: amplicons labelled with digoxigenin on one side and biotin on the other side (DIG-labelled) if Listeria monocytogenes template DNA was present and amplicons labelled with fluorescein and biotin (FL-labelled) if Listeria spp. DNA was present.

Immune reagents

NeutrAvidin Biotin-Binding Protein was from Pierce Biotechnology (Rockford, IL, USA) and Biotin-SP-conjugated AffiniPure Goat Anti-Mouse IgG (Biotin, 2000 ng IgG/ $5 \mathrm{~mm}$ ) was from Jackson ImmunoResearch (Suffolk, UK). Affinity-purified goat anti-fluorescein antibody (anti-FL, $500 \mathrm{ng} / 5 \mathrm{~mm}$ ) was obtained from Biomeda (Foster City, CA, USA) and polyclonal anti-digoxigenin antibody (antiDIG, $200 \mathrm{ng} / 5 \mathrm{~mm}$ ) was from Roche Diagnostics (Basel, Switzerland).

Nucleic acid lateral flow immunoassay

As an assay format for preliminary characterization, an experimental setup using the wells of a microtitrate plate was used. A tube format [28] was applied for final evaluation of the assay with food samples (Fig. 1).
Antibodies were immobilized on nitrocellulose membranes by spraying using a Linomat V (CAMAG, Muttenz, Switzerland). A control line (CL) was added by spraying Biotin-conjugated AffiniPure Goat Anti-Mouse IgG, a test line specific to all species from the genus Listeria (TL1) by spraying anti-FL, and a test line specific to Listeria monocytogenes (TL2) by spraying anti-DIG.

Following PCR, $3 \mu \mathrm{l}$ of the reaction mixture containing the specific amplicons was mixed with $1 \mu \mathrm{l}$ of carbon nanoparticles-NeutrAvidin conjugate, able to interact with the biotin-labelled amplicons, and running buffer $(100 \mathrm{mM}$ borate buffer, $\mathrm{pH} 8.8,1 \%$ (w/v) BSA, $0.05 \%$ (v/v) Tween $\left.20,0.02 \%(\mathrm{w} / \mathrm{v}) \mathrm{NaN}_{3}\right)$ to a total volume of $100 \mu \mathrm{l}$. The mixture was run through nitrocellulose membranes and the result was read after maximally $15 \mathrm{~min}$. Typical NALFIA results are shown in Fig. 2, together with electrophoresis. Labelled amplicons from samples containing L. monocytogenes (Fl- and DIG-labelled) were demonstrated by the appearance of three grey/black lines. Samples with the Listeria spp. but not L. monocyotogenes contained FLlabelled amplicons and were indicated by the appearance of two grey/black lines. PCR product prepared from samples without listeria template DNA showed only one grey/black line (control line).

Sensitivity analysis of NALFIA

Dilution ranges of DIG- and FL-labelled amplicons were prepared and tested in NALFIA. Amplicon concentrations were determined by the spectrophotometer NanoDrop (ND 1000, NanoDrop Technologies). Test lines were scanned 


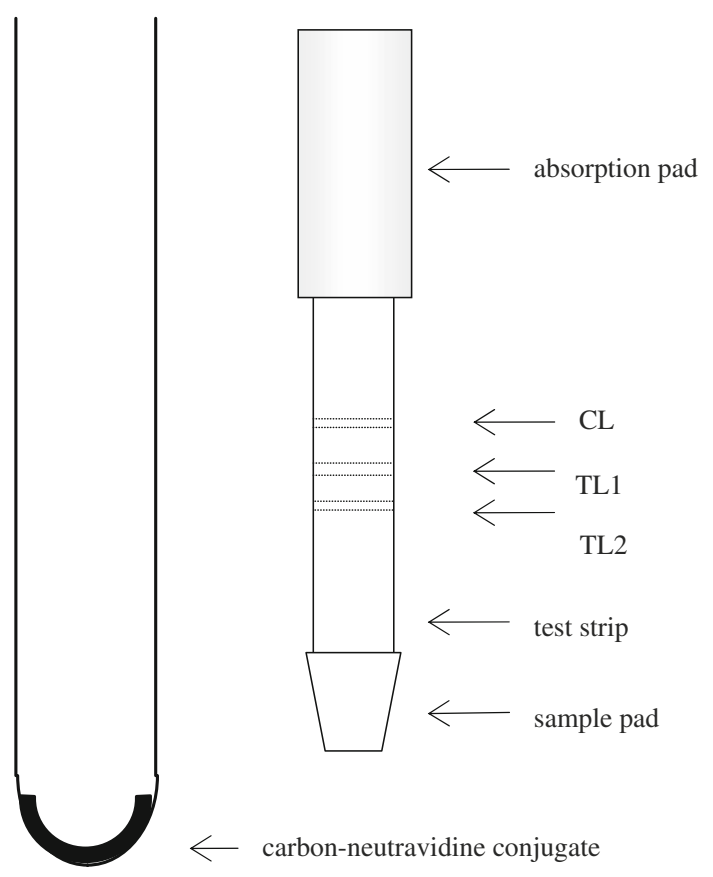

Fig. 1 A schematic drawing of a one-step tube assay [28]. CarbonNeutrAvidin conjugate is dried on the bottom of the tube. Sample is applied on top of the conjugate and the strip is placed into the tube. If L. monocytogenes is present three grey/black lines will appear, if other Listeria species are present two lines will appear, and if the sample is negative only one control line will appear. $C L$ control line formed by Biotin-conjugated AffiniPure Goat Anti-Mouse IgG, TL1 test line specific to all species from the genus Listeria formed by $\alpha$ FL, TL2 test line specific to Listeria monocytogenes formed by $\alpha$-DIG

with a flatbed scanner (Epson Perfection V700 Photo) and the line intensities were converted to pixel grey volumes with TotalLab (Nonlinear Dynamics, Ltd.). Curve fitting was done with Excel (Microsoft Office).

\section{Results and discussion}

\section{Development of NALFIA for Listeria detection}

We present a rapid, reliable, and specific immunochromatographic tube assay for simultaneous nucleic acid detection of Listeria spp. and L. monocytogenes.

The developed procedure consists of an enrichment step $(24 \mathrm{~h})$, isolation of template DNA and a PCR amplification step of specific sequences $(3.5 \mathrm{~h})$, and an immunochromatographic detection of amplified product by NALFIA (5-15 min). To our knowledge, this is the first time that this combination of PCR and immunochromatographic one-step detection is described for Listeria. The combination of both techniques into an assay for rapid detection of specific nucleic acid targets was already described for detection of the mecA gene from methicillin-resistant Staphylococcus aureus (MRSA) cultures [29], for direct diagnosis of Porphyromonas gingivalis [30], and for the identification of Mycobacterium tuberculosis [31].

For an optimal NALFIA result, the duplex PCR based on published results [26, 27] was slightly adjusted. In addition, FastStart Taq DNA polymerase was used for all experiments. Primers and polymerase concentrations were chosen to reach comparable intensities of the test lines: the L. monocytogenes specific line and the generic Listeria spp. line. By using the adapted protocol (see "Materials and methods"), the results appeared to be very reproducible. The performance of NALFIA was optimized in experiments in which the amounts of the carbonNeutrAvidin conjugate, the concentration of immobilized capture antibody, and/or the volume of the PCR product varied.
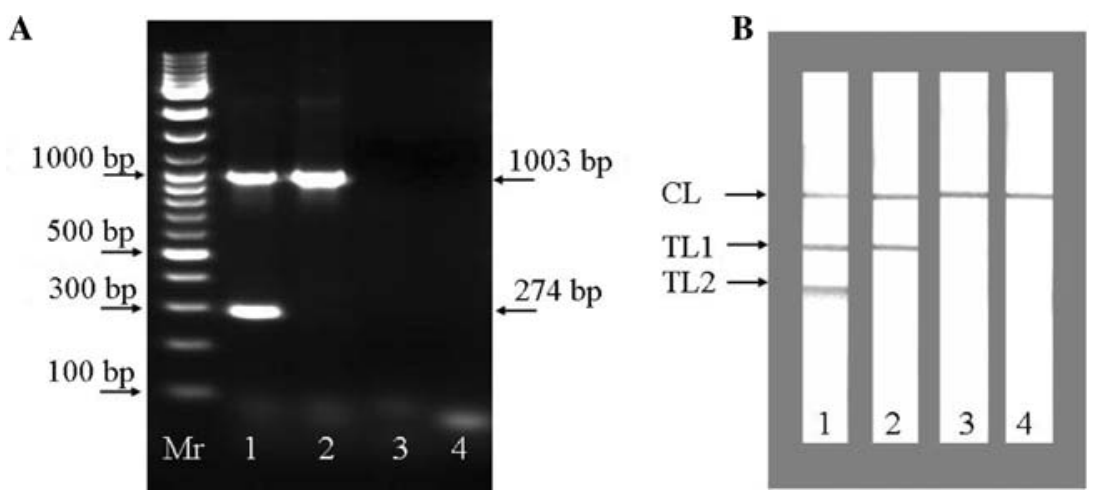

Fig. 2 Typical results of simultaneous detection of $L$. monocytogenes and generic Listeria spp. amplicons by agarose gel electrophoresis (a) and NALFIA (b) after duplex PCR. For both a and b, chromosomal DNA of L. monocytogenes (lane 1), L. innocua (lane 2), and Enterobacter cloacae (lane 3) was used for duplex PCR. The negative control (lane 4) is a primer control (PCR without template DNA). $M r$ DNA size marker, TL1 test line specific to all species from genus Listeria (line of $\alpha$-FL), TL2 test line specific to L. monocytogenes (line of $\alpha$-DIG), $C L$ control line (IgG-biotin) 
The specificity and sensitivity of the developed NALFIA

The specificity of the described NALFIA was studied by testing a range of Listeria strains and other food-relevant

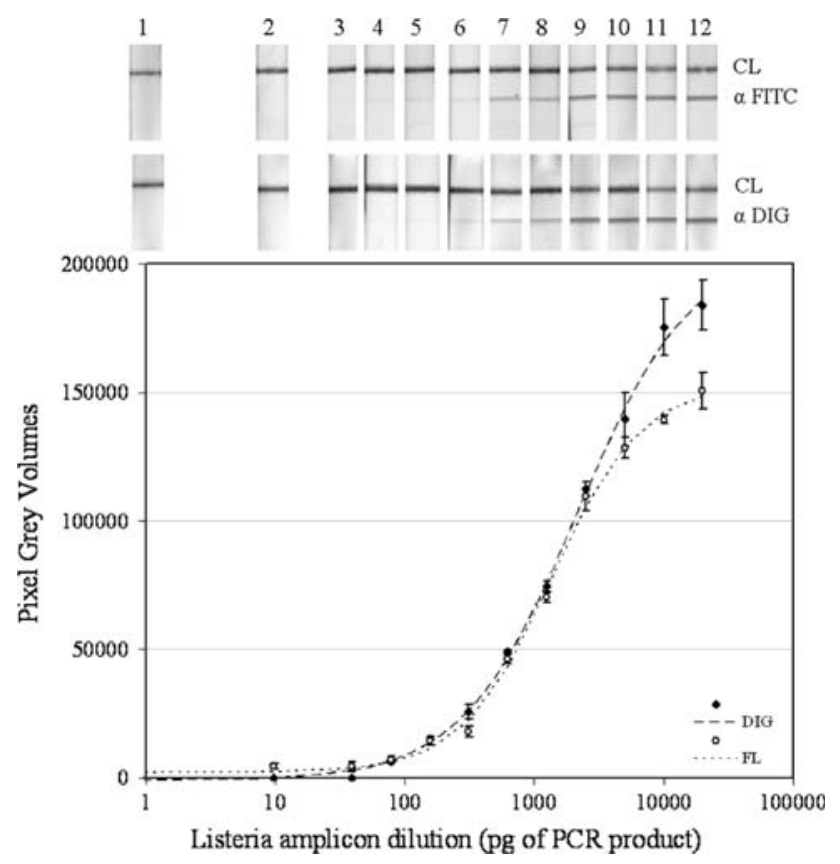

Fig. 3 Limit of detection of Listeria-NALFIA. Dilution series of amplified material of L. monocytogenes were tested by NALFIA. For generic Listeria detection, primers C, D (FL-labelled) were used in PCR, and for specific detection of L. monocytogenes, primers LIP1 and LIP2 were used (DIG-labelled). The upper panel shows scanned results obtained by NALFIA. The dilution range included $0 \mathrm{ng}$ (lane 1), $0.01 \mathrm{ng}$ (lane 2), $0.04 \mathrm{ng}$ (lane 3), $0.08 \mathrm{ng}$ (lane 4), $0.156 \mathrm{ng}$ (lane 5), $0.313 \mathrm{ng}$ (lane 6), $0.625 \mathrm{ng}$ (lane 7), $1.25 \mathrm{ng}$ (lane 8), $2.5 \mathrm{ng}$ (lane 9), $5 \mathrm{ng}$ (lane 10), $10 \mathrm{ng}$ (lane 11), and $20 \mathrm{ng}$ (lane 12). The lower panel shows the calculated pixel grey volumes after flatbed scanning and image analysis. Each point represents the mean of 3 values \pm standard deviation. Results achieved with PCR material amplified with primers C, D (FL-labelled) is marked with open symbol, and PCR material amplified with primers LIP1 and LIP2 (DIG-labelled) with closed symbol microorganisms (Table 1). PCR products of nine tested $L$. monocytogenes strains bound with both capture lines (the anti-DIG and the anti-FL line) and control line (CL); PCR products of all (5) other non-pathogenic Listeria only bound to the anti-FL line and control line. PCR products from 14 food-related, non-listerial microorganisms, the primers control (PCR without template DNA), and the buffer control (running buffer without PCR material) were negative and bound only to the control line (data not shown).

The sensitivity of NALFIA was set as the minimal concentrations of PCR amplicons that resulted in specific lines on the test membrane. Results are presented in Fig. 3 and show the dynamic range of NALFIA being 2.5-3 orders of magnitude for the DIG and FL assays. The lowest visually detectable amount was $0.1 \mathrm{ng}$ of labelled amplicon.

With the optimized procedure, the lowest detectable amount of template DNA used for PCR was $50 \mathrm{pg}$ of L. monocytogenes template DNA (Fig. 4), correlating with approximately $10^{5}$ cells (Fig. 5), assuming a DNA content of $10^{-6} \mathrm{ng}$ per cell [32]. These results corresponded to data received from experiments without pre-cultivation in which we were able to detect $10^{5}$ cells in $1 \mathrm{ml}$ of sample (Fig. 5).

Comparative costs and safety

The comparative costs and safety of electrophoresis and the typical NALFIA results are shown in Table 2. Electrophoresis is slightly cheaper in comparison with NALFIA, mainly due to the costs of labelled primers and components of immunochromatographic test (antibodies). On the other hand, NALFIA is user friendly, more rapid, less laborious (costs saving in personnel), and without any biological hazard.

Application of NALFIA to model milk samples

The Listeria-NALFIA technique was adapted to a tube format (see Fig. 1, [28]) to enable easy handling whilst

Table 2 Comparative costs and safety of NALFIA and electrophoresis including preparation of the sample

\begin{tabular}{lll}
\hline & NALFIA & Electrophoresis \\
\hline Assessed price per 100 tests (in $€$ ) & & \\
Cultivation, DNA isolation, PCR (without primers) & 250 & 250 \\
Primers & 4 (labelled) & $<1$ \\
Visualization & 13 (antibodies, carbon) & 5 (ethidium bromide) \\
Test components & 4 (membranes, pads) & 8 (agarose/gels) \\
Total price per 100 tests (in $€$ ) & 271 & 264 \\
Time for visualization of results & 10 min & $30-60$ min \\
Required laboratory equipment & None & Electrophoresis station, UV transluminator, Photosystem \\
Labour costs (electrophoresis $=100 \%)$ & $80 \%$ & $100 \%$ \\
Biological hazard & None & Ethidium bromide \\
\hline
\end{tabular}



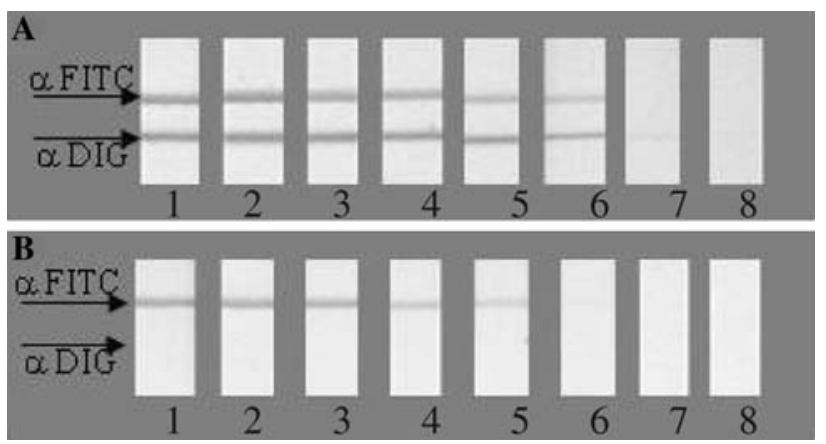

Fig. 4 Detection limit of duplex PCR-NALFIA. The detection limit of the assay was evaluated by using a diluted DNA of $L$. monocytogenes (a) and L. innocua (b). Dilution range included $10 \mathrm{ng}$ (lane 1), $5 \mathrm{ng}$ (lane 2), $2.5 \mathrm{ng}$ (lane 3), $0.5 \mathrm{ng}$ (lane 4), $0.25 \mathrm{ng}$ (lane 5), $0.05 \mathrm{ng}$ (lane 6), $0.01 \mathrm{ng}$ (lane 7), and $0.005 \mathrm{ng}$ (lane 8). Amplified DNA products were detected by NALFIA
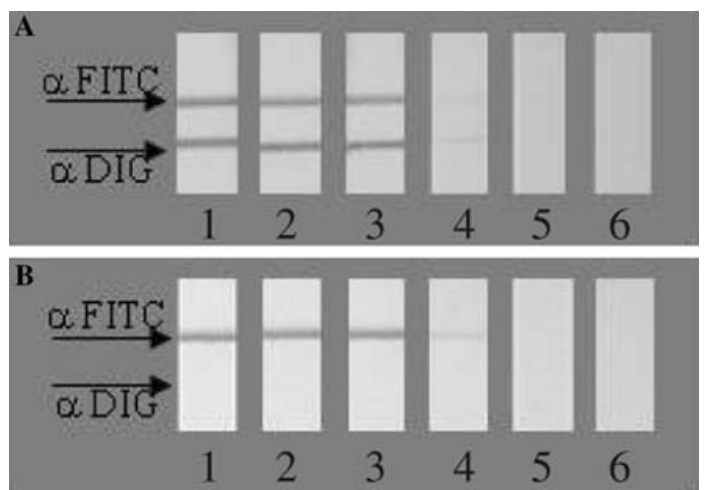

Fig. 5 Detection of cells dilutions. Multi-analyte NALFIA detection of PCR material that was prepared with DNA isolated from a dilution series of overnight cultures $L$. monocytogenes (a) and L. innocua (b). $110^{8}$ cells, $210^{7}$ cells, $310^{6}$ cells, $410^{5}$ cells, $510^{4}$, and $610^{3}$ cells used for isolation

reducing the overall costs of the assay. The method was finally verified by testing samples of sterilized milk that had been artificially contaminated with low amounts of different bacteria, including four different strains of $L$. monocytogenes, two strains of non-pathogenic Listeria, and E. faecalis. With the developed Listeria-NALFIA, less than 10 cells of $L$. monocytogenes/Listeria spp. were detected in $25 \mathrm{ml}$ of milk within $28 \mathrm{~h}$ ( $24 \mathrm{~h}$ for cultivation, $4 \mathrm{~h}$ for PCR and NALFIA). No non-specific signals were visible when control samples (E. faecalis in milk, clear milk) were run (Fig. 6). The commercially available tests for specific detection of L. monocytogenes allow detecting L. monocytogenes within $37-54 \mathrm{~h}$, whereas the current reference method for the detection of $L$. monocytogenes as proposed by ISO [12] allows the recovery of this pathogen in 5-7 days. The developed NALFIA procedure considerably reduces the total analysis time since the results can be obtained within $28 \mathrm{~h}$ from sample receipt. The application of NALFIA after cultural enrichment guarantees that target DNA is obtained from viable cells; damaged cells cannot result in false-positive lines.

\section{Application of NALFIA to real food-related samples}

The verified NALFIA was applied to a total of 24 real samples prepared from different types of food or food-related samples. The results are summarized in Table 3. Of the 24 tested samples, 15 contained Listeria spp. and 5 were positive for L. monocytogenes. All samples were also tested by the microbiological standard method and identical results as with NALFIA were obtained. Our results indicate that NALFIA can be a helpful tool for easier incorporation of molecular-biological methods as a routine diagnostic procedure for the identification of food-borne pathogens.

\section{Conclusion}

A rapid, specific, and user-friendly test for detection of $L$. monocytogenes is urgently needed by the food industry. In
Fig. 6 Listeria-NALFIA in tube format. PCR material was derived from milk samples that were incurred with various bacterial (sub)species: $1 \mathrm{~L}$. monocytogenes (ALM 92, nr. 1 of triplicate), $2 \mathrm{~L}$.

monocytogenes (ALM 92, nr.2 of triplicate), $3 \mathrm{~L}$.

monocytogenes (ALM 92, nr.3 of triplicate), $4 \mathrm{~L}$. monocytogenes (NCTC 4886), 5 L. monocytogenes (NCTC 4885), 6 L. monocytogenes (milk from IFR), 7 L. innocua, 8 L. ivanovii, 9 Enterococcus faecalis, and 10 negative milk control

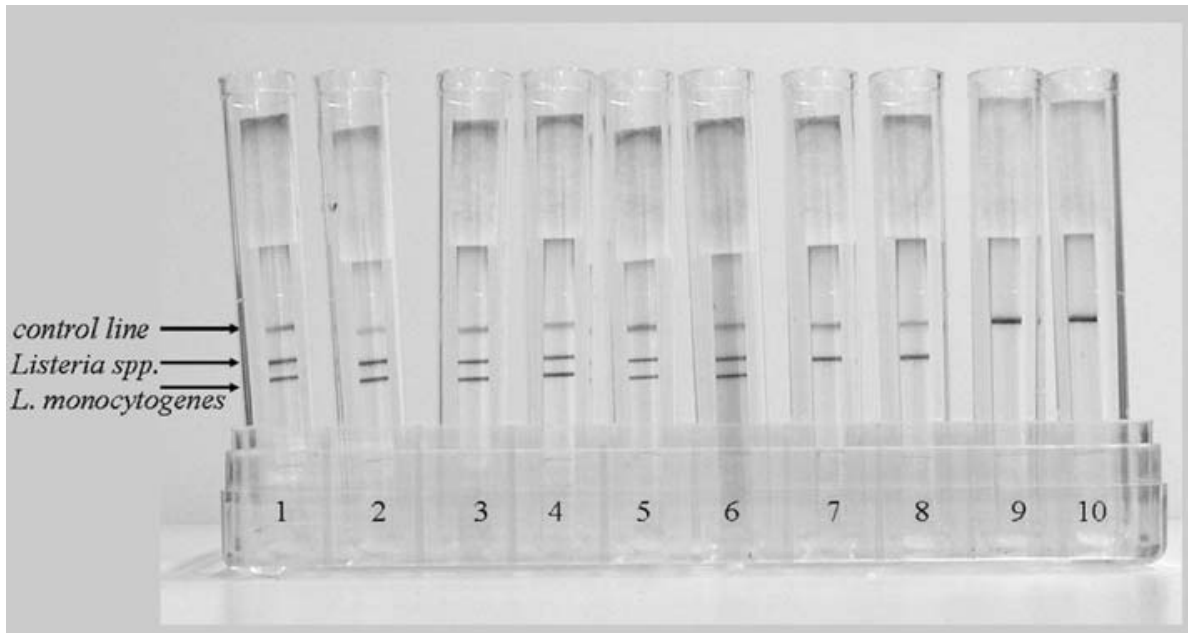


Table 3 Results of the detection tests for listeria presence in food and biofarm samples

\begin{tabular}{|c|c|c|}
\hline \multirow[t]{2}{*}{ Food } & \multicolumn{2}{|l|}{ Results } \\
\hline & NALFIA & $\begin{array}{l}\text { Microbiological } \\
\text { method }\end{array}$ \\
\hline \multicolumn{3}{|l|}{ Diary products } \\
\hline Milk & neg & neg \\
\hline Ice cream & neg & neg \\
\hline Soft-dried cream cheese & $\mathrm{Lm}$ & $\mathrm{Lm}$ \\
\hline \multicolumn{3}{|l|}{ Vegetable } \\
\hline Broccoli & $\mathrm{Lm}$ & Lm \\
\hline Spinach & $\mathrm{gL}$ & $\mathrm{gL}$ \\
\hline \multicolumn{3}{|l|}{ Ready-to-eat salad } \\
\hline Potato salad & $\mathrm{gL}$ & $\mathrm{gL}$ \\
\hline Delicacy salad & neg & neg \\
\hline \multicolumn{3}{|l|}{ Sprouted seeds } \\
\hline Snail-clover/alfalfa & neg & neg \\
\hline Mongoose & neg & neg \\
\hline \multicolumn{3}{|l|}{ Nutrition for children } \\
\hline Vegetables with turkey & neg & neg \\
\hline Bilberries & neg & neg \\
\hline Frozen bilberries & $\mathrm{Lm}$ & $\mathrm{Lm}$ \\
\hline \multicolumn{3}{|l|}{ Biofarm samples } \\
\hline Raw milk & $\mathrm{gL}$ & $\mathrm{gL}$ \\
\hline Water & neg & neg \\
\hline Silage & $\mathrm{gL}$ & $\mathrm{gL}$ \\
\hline Hay & $\mathrm{gL}$ & $\mathrm{gL}$ \\
\hline Faeces & $\mathrm{gL}$ & $\mathrm{gL}$ \\
\hline Surface sample—nipple & neg & neg \\
\hline Surface sample-floor & $\mathrm{gL}$ & $\mathrm{gL}$ \\
\hline \multicolumn{3}{|l|}{ Inter-lab trials } \\
\hline Pasta A & $\mathrm{gL}$ & $\mathrm{gL}$ \\
\hline Pasta B & $\mathrm{Lm}$ & $\mathrm{Lm}$ \\
\hline Dried milk A & $\mathrm{Lm}$ & $\mathrm{Lm}$ \\
\hline Dried milk B & $\mathrm{gL}$ & $\mathrm{gL}$ \\
\hline Dried milk C & $\mathrm{gL}$ & $\mathrm{gL}$ \\
\hline
\end{tabular}

neg negative result, $L m$ presence of $L$. monocytogenes detected, $g L$ presence of bacteria from genus Listeria detected

a procedure in which the Listeria-NALFIA was applied, we have shown that the approach of using the combination of nucleic acid amplification and an immunochemicalbased detection principle offers favourable advantages in terms of sensitivity, specificity, costs, and especially speed. Furthermore, since the Listeria-NALFIA simultaneously detects Listeria spp. and L. monocytogenes, this method will help to improve the microbiological standards of foodstuffs. This method not only helps to point at the hygienically errors in food production indicated by the Listeria spp. presence but it also reveals dangerous contamination by the human pathogen L. monocytogenes.
Acknowledgments This work was supported by the grants from Ministry of Education of Czech Republic 2B08050 and MSM 604613 7305 (author Martina Blažková), which were really appreciated.

Open Access This article is distributed under the terms of the Creative Commons Attribution Noncommercial License which permits any noncommercial use, distribution, and reproduction in any medium, provided the original author(s) and source are credited.

\section{References}

1. Mead PS, Slutsker L, Dietz V, McCaig LF, Bresee JS, Shapiro C, Griffin PM, Tauxe RV (1999) Emerg Infect Dis 5:607-625

2. European Food Safety Authority (2006) EFSA J 310, ISBN: $92-$ 9199-016-7

3. Vázquez-Boland A, Kuhn M, Berche $\mathrm{P}$, Chakraborty $\mathrm{T}$, Domínguez-Bernal G, Goebel W, Gonzáles-Zorn B, Wehland J, Kreft J (2001) Clin Microbiol Rev 14(3):584-640

4. Gandhi M, Chikindas ML (2007) Int J Food Microbiol 113:1-15

5. Gray ML, Killinger AH (1966) Bacteriol Rev 30(2):309-382

6. Ramaswamy V, Cresence VM, Rejitha JS, Lekshmi MU, Dharsana KS, Prasad SP, Vijila HM (2007) J Microbiol Immunol Infect 40:4-13

7. WHO (2002) Foodborne diseases, emerging. http://www.who.int

8. Leverentz B, Conway WS, Janisiewicz W, Abadias M, Kurtzman CP, Camp MJ (2006) Appl Environ Microbiol 72(2):1135-1140

9. MacDonald PDM, Whitwam RE, Boggs JD, MacCormack JN, Anderson KL, Reardon JW, Saah RJ, Graves LM, Hunter SB, Sobel J (2005) Clin Infect Dis 40:677-682

10. El Amin A (2006) http://www.foodqualitynews.com/news/ng. asp?n=71566-fsa-salads-listeria. Accessed 10 Sept 2008

11. Commission Regulation (EC) No 1441/2007 of 5 December 2007 amending Regulation (EC) No 2073/2005 on microbiological criteria for foodstuffs

12. International Standard ISO 11290-1 (1996) Part 1: Detection method

13. Ottaviani F, Ottaviani M, Agosti M (1997) In: Quimper Froid symposium proceedings, France, 16-18 June 1997, ADRIA Quimper, p 6

14. Sacchetti R, Bianucci F, Ambrogiani E (2003) New Microbiol 26(3):269-274

15. Vlaemynck G, Lafarge V, Scotter S (2000) J Appl Microbiol 88:430-441

16. Gasanov U, Hughes D, Hansbro PM (2005) FEMS Microbiol Rev 29:851-875

17. Feldsine PT, Lienau AH, Leung SC, Mui LA (2002) J AOAC Int 85(2):470-478

18. Karamonová L, Blažková M, Fukal L, Rauch $\mathrm{P}$, Greifová M, Horáková K, Tomáška M, Roubal P, Brett GM, Wyatt GM (2003) Food Agric Immunol 15:167-182

19. Blažková M, Karamonová L, Greifová M, Fukal L, Hoza I, Rauch P, Wyatt GM (2006) Eur Food Res Technol 223:821-827

20. Nugen SR, Baeumner AJ (2008) Anal Bioanal Chem 391:451454

21. Kaclíková E, Pangallo D, Drahovská H, Oravcová K, Kuchta T (2003) Food Control 14:175-179

22. Hochberg AM, Roering A, Gangar V, Curiale M, Barbour WM, Mroyinski PM (2001) J AOAC Int 84(4):1087-1097 ISSN 10603271

23. Amagliani G, Giammarini C, Omiccioli E, Brandi G, Magnani M (2007) Food Control 18:1137-1142

24. van Amerongen A and Koets M (2005) In: van Amerongen A, Barug D, Lauwaars M (eds) Rapid methods for biological and 
chemical contaminants in food and feed. Wageningen Academic Publishers, Wageningen, The Netherlands. ISBN: 9076998531

25. Baptista P, Pereira E, Eaton P, Doria G, Miranda A, Gomes I, Quaresma P, Franco R (2008) Anal Bioanal Chem 397:943-950

26. Herman LMF, de Ridder HFM, Vlaemynck GMM (1995) J Food Prot 58(8):867-872

27. D'Agostino M, Wagner M, Vazquez-Boland JA, Kuchta T, Karpiskova R, Hoorfar J, Novella A, Scortii M, Ellison J, Murray A, Fernandes I, Kuhn M, Pazlarova J, Heuvelink A, Cook N (2004) J Food Prot 67(8):1646-1655

28. Koets M, Sander I, Bogdanovic J, Doekes G, van Amerongen A (2006) J Environ Monit 8(9):942-946

29. Fong WK, Modrusan Z, McNevin JP, Marostenmaki J, Zin B, Bekkaoui F (2000) J Clin Microbiol 38(7):2525-2529
30. Takada K, Sakaguchi Y, Oka C, Hirasawa M (2005) J Periodontol 76(4):508-512

31. Soo P-Ch, Horng Y-T, Hsueh P-R, Shen B-J, Wang J-Y, Tu H-H, Wei J-R, Hsieh S-Ch, Huang Ch-Ch, Lai H-Ch (2006) J Microbiol Methods 66(3):440-448

32. Nelson KE, Fouts DE, Mongodin EF, Ravel J, DeBoy RT, Kolonay JF, Rasko DA, Angiuoli SV, Gill SR, Paulsen IT, Peterson J, White O, Nelson WC, Nierman W, Beanan MJ, Brinkac LM, Daugherty SC, Dodson RJ, Durkin AS, Madupu R, Haft DH, Selengut J, Aken SV, Khouri H, Fedorova N, Forberger H, Tran B, Kathariou S, Wonderling LD, Uhlich GA, Bayles DO, Luchansky JB, Fraser CM (2004) Nucleic Acids Res 32(8):23862395 